\title{
A standard bacterial isolate set for research on contemporary dairy spoilage
}

\section{A. Trmčić, N. H. Martin, K. J. Boor, and M. Wiedmann ${ }^{1}$}

Milk Quality Improvement Program, Department of Food Science, Cornell University, Ithaca, NY 14850

\begin{abstract}
Food spoilage is an ongoing issue that could be dealt with more efficiently if some standardization and unification was introduced in this field of research. For example, research and development efforts to understand and reduce food spoilage can greatly be enhanced through availability and use of standardized isolate sets. To address this critical issue, we have assembled a standard isolate set of dairy spoilers and other selected nonpathogenic organisms frequently associated with dairy products. This publicly available bacterial set consists of (1) 35 gram-positive isolates including 9 Bacillus and 15 Paenibacillus isolates and (2) 16 gram-negative isolates including 4 Pseudomonas and 8 coliform isolates. The set includes isolates obtained from samples of pasteurized milk $(\mathrm{n}=43)$, pasteurized chocolate milk $(\mathrm{n}=1)$, raw milk $(\mathrm{n}=1)$, cheese $(\mathrm{n}=$ 2 ), as well as isolates obtained from samples obtained from dairy-powder production $(\mathrm{n}=4)$. Analysis of growth characteristics in skim milk broth identified 16 gram-positive and 13 gram-negative isolates as psychrotolerant. Additional phenotypic characterization of isolates included testing for activity of $\beta$-galactosidase and lipolytic and proteolytic enzymes. All groups of isolates included in the isolate set exhibited diversity in growth and enzyme activity. Source data for all isolates in this isolate set are publicly available in the FoodMicrobeTracker database (http://www.foodmicrobetracker. com), which allows for continuous updating of information and advancement of knowledge on dairy-spoilage representatives included in this isolate set. This isolate set along with publicly available isolate data provide a unique resource that will help advance knowledge of dairy-spoilage organisms as well as aid industry in development and validation of new control strategies.
\end{abstract}

Key words: isolate set, dairy spoilage, fluid milk, dairy powder, cheese

\section{INTRODUCTION}

Dairy processors, together with the rest of the food industry, are striving toward extending the shelf-life

Received February 20, 2015.

Accepted April 11, 2015.

${ }^{1}$ Corresponding author: mw16@cornell.edu of their products while following the modern trends of minimal processing. Despite the advances in food handling and processing, a large amount of milk and dairy products are still being wasted every year. The USDA Economic Research Service (USDA, 2012) estimates loss to be more than $29 \%$ for fluid and fermented milk and more than $27 \%$ for cheese. Although a large proportion of these losses appears to occur at the consumer and retail level (Golan and Buzby, 2015), microbial spoilage appears to represent an important contributor to these losses (Remenant et al., 2015).

Spoilage microorganisms in fluid milk are usually responsible for 2 types of spoilage. One type of spoilage is typically associated with postpasteurization contamination (PPC) and leads to rapid spoilage of fluid milk within 7 to $14 \mathrm{~d}$. Most postpasteurization contaminants that lead to fluid-milk spoilage represent psychrotolerant gram-negative bacteria, including Pseudomonas species, coliforms, and other members of the Enterobacteriaceae family (Boor, 2001; Martin et al., 2012a). With advances in process control and reduction in occurrence of $\mathrm{PPC}$, spoilage of fluid milk due to outgrowth of aerobic, gram-positive, sporeforming bacteria has become more apparent. This type of spoilage is caused by different psychrotolerant bacilli, which mainly represent the genus Paenibacillus and some Bacillus species such as B. weihenstephanensis (Ranieri and Boor, 2009; Ivy et al., 2012; Ranieri et al., 2012). Spoilage due to these organisms typically occurs around 17 to $21 \mathrm{~d}$ of shelf-life if milk is stored around $6^{\circ} \mathrm{C}$. Both sporeforming and nonsporeforming gram-positive bacteria are also occasionally involved in PPC. In this type of spoilage the onset can be more rapid, suggesting contamination with viable bacterial cells, which are not delayed by the germination process of spores.

Aerobic, gram-positive, sporeforming bacteria are also important contaminants of dairy powders. High temperatures involved in production of dairy powders select for thermophilic bacilli, which can influence the stability of dairy powders and reconstituted dairy powders. The majority of isolates obtained from different dairy powders belong to 1 of 3 members of family Bacillaceae, including Anoxybacillus flavithermus, Geobacillus stearothermophilus, and Bacillus licheniformis. Besides these 3 most prevalent species, dairy powders 
can also contain other species and genera from this family (Ronimus et al., 2003; Rückert et al., 2004; Watterson et al., 2014).

Bacterial contaminants also play an important role in cheese spoilage. Similarly to fluid milk, psychrotolerant, gram-negative bacteria, such as Pseudomonas and coliform bacteria, are known to cause spoilage of cottage cheese and other fresh dairy products (Lemieux and Simard, 1992; Martin et al., 2011a). Coliform bacteria are also known to cause several defects in hard-type cheese, including early blowing. Late blowing most often associated with Swiss-type cheese is caused by Clostridium tyrobutyricum, an anaerobic, gram-positive, sporeforming bacterium (Cogan and Beresford, 2002).

Different isolate sets and reference isolate sets are a well-established resource in research and development. An early example of such an isolate set is the Escherichia coli diversity collection developed by Ochman and Selander in 1984 (Ochman and Selander, 1984). Since then other isolate sets have been introduced, which are mostly capturing isolate diversity within a specific pathogen group, such as Salmonella (Boyd et al., 1993), Listeria monocytogenes (Fugett et al., 2006), Cronobacter (Ivy et al., 2013), and as the most recent example, Clostridium difficile (Janezic et al., 2014). Isolate sets like these are used in development of new detection methods and control measures as well as studies that characterize a given group of microorganisms. The success of different pathogen isolate sets and collections could be extended from pathogenic bacteria to also other microbial groups of interest, such as spoilage bacteria.

The objective of this study was to assemble and offer a publicly available isolate set of contemporary bacterial isolates that are known to cause or have the potential to cause spoilage of fluid milk and dairy products. We anticipate that this isolate set together with the availability of updated isolate data, through the FoodMicrobeTracker database (formerly known as Pathogen Tracker; Vangay et al., 2013), will provide a valuable tool for studying bacterial dairy spoilers as well as provide the means for unification and faster progress in dairy research and technology.

\section{MATERIALS AND METHODS}

\section{Isolates}

Isolates included in this isolate set of dairy spoilers are listed in the Table 1 and were obtained from a large collection of isolates that have been collected as part of several dairy-quality research and surveillance projects conducted by Cornell's Milk Quality Improvement Pro- gram. The complete isolate set consists of 51 individual isolates, 35 isolates representing gram-positive and 16 isolates representing gram-negative bacteria. The isolates originated from different samples of pasteurized milk $(\mathrm{n}=43)$, pasteurized chocolate milk $(\mathrm{n}=1)$, raw milk $(\mathrm{n}=1)$, cheese $(\mathrm{n}=2)$, and also from samples obtained from dairy-powder production $(\mathrm{n}=4)$. Although the majority of these isolates are described here for the first time, 20 isolates have been described in previously published studies (Huck et al., 2007b, 2008; Ranieri and Boor, 2009; Ranieri et al., 2009; Martin et al., 2011a; Ivy et al., 2012; Van Tassell et al., 2012; Moreno Switt et al., 2014; Watterson et al., 2014). Isolates are stored at $-80^{\circ} \mathrm{C}$ in brain heart infusion $(\mathbf{B H I})$ broth (Difco, BD, Sparks, MD) with $15 \%$ glycerol as part of culture collection maintained by the Food Safety Laboratory (FSL), Department of Food Science, Cornell University, Ithaca, New York.

\section{Identification by DNA Sequencing-Based Methods}

All isolates included in the isolate set were identified by sequencing part of the $16 \mathrm{~S}$ rDNA or rpoB or both. Sequencing of rро $B$ was used to identify isolates from the family Bacillaceae, as previously described (Huck et al., 2007a; Ivy et al., 2012). Briefly, rpoB data were initially used to classify isolates into an rро $B$ allelic type (AT); 2 isolates are classified into the same AT if they share identical sequence of the 632-nt rpoB fragment analyzed. At least one isolate for a given rpoB AT was also characterized by a partial $16 \mathrm{~S}$ rDNA sequencing. A 616-nt fragment of $16 \mathrm{~S} \mathrm{rDNA}$ was analyzed to aid in genus and species classification of isolates with a given rро $B$ AT. A large rpoB sequence database linked to appropriate $16 \mathrm{~S}$ rDNA-based genus and species data is used to facilitate this characterization method, which has been widely used in the past (Huck et al., 2007a,b; Huck et al., 2008; Ranieri and Boor, 2009; Ranieri et al., 2009; Ivy et al., 2012; Masiello et al., 2014).

For identification, individual colonies of a given isolate were first streaked onto a BHI agar plate, followed by overnight incubation at appropriate temperature $\left(21,32,37\right.$, or $\left.55^{\circ} \mathrm{C}\right)$, to obtain individual colonies. A single colony was transferred into a $0.2-\mathrm{mL}$ PCR tube using a sterile toothpick, followed by lysis by heating in a 1,200-W microwave for $3 \mathrm{~min}$. The obtained lysate was resuspended in $50 \mu \mathrm{L}$ of nuclease-free water, and 2 $\mu \mathrm{L}$ of a given lysate was used to perform a $25-\mu \mathrm{L}$ PCR, amplifying either a 740-nt rpoB fragment or a 763-nt $16 \mathrm{~S}$ rDNA fragment. The PCR products were verified for size using gel electrophoresis and purified using the ExoSAP method (Dugan et al., 2002). Bidirectional Sanger sequencing of the PCR product was performed 
TRMČIĆ ET AL.

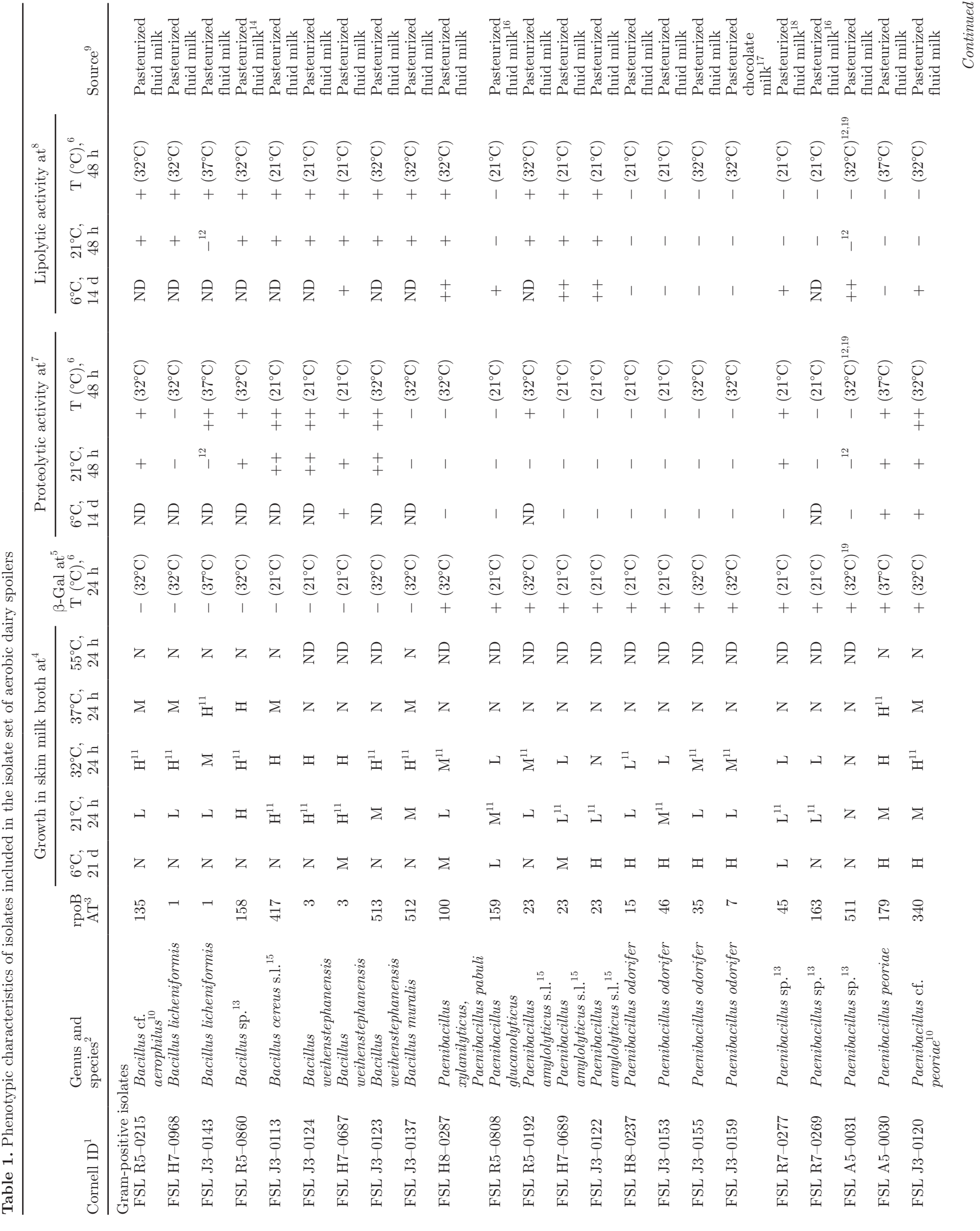




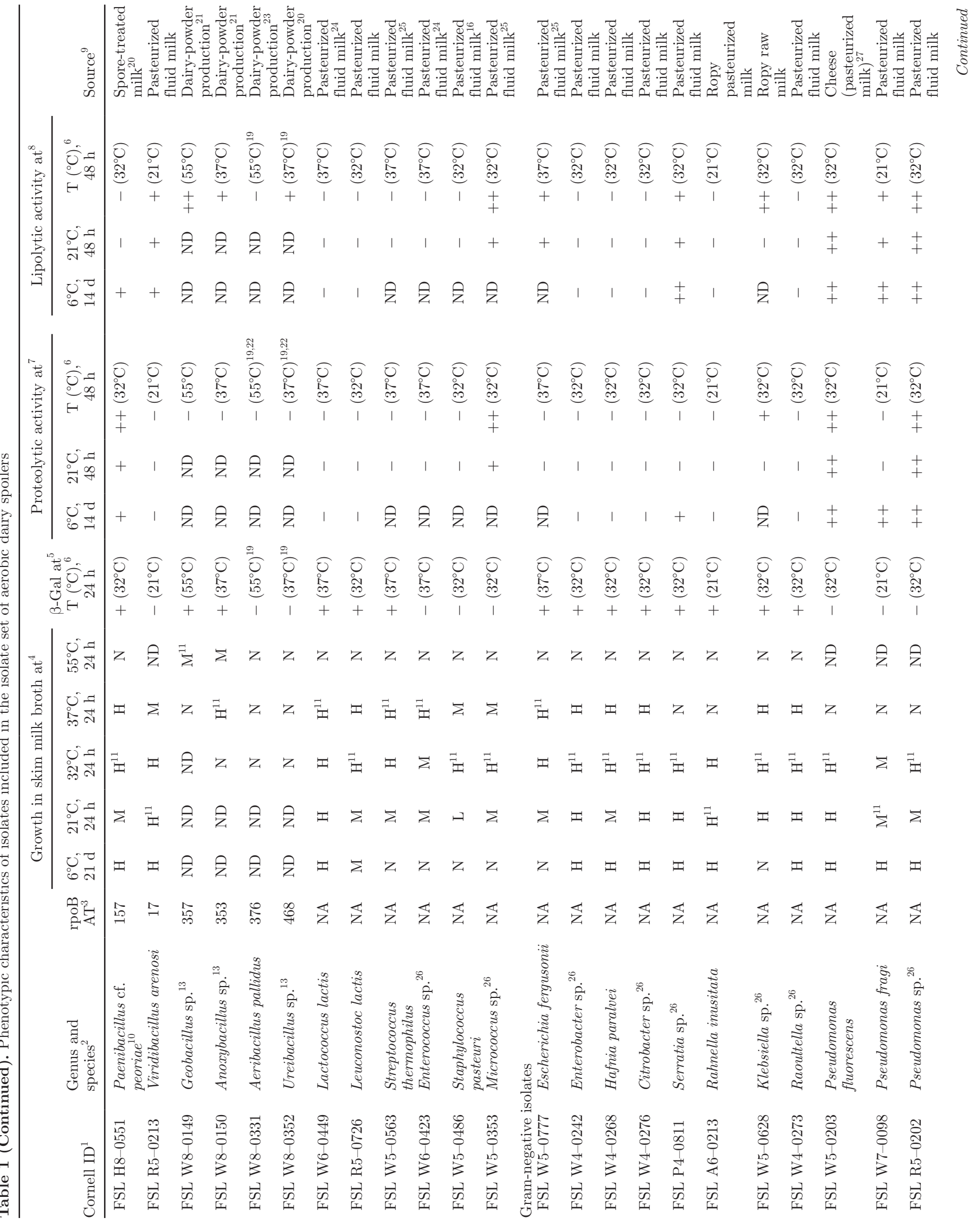


TRMČIĆ ET AL.

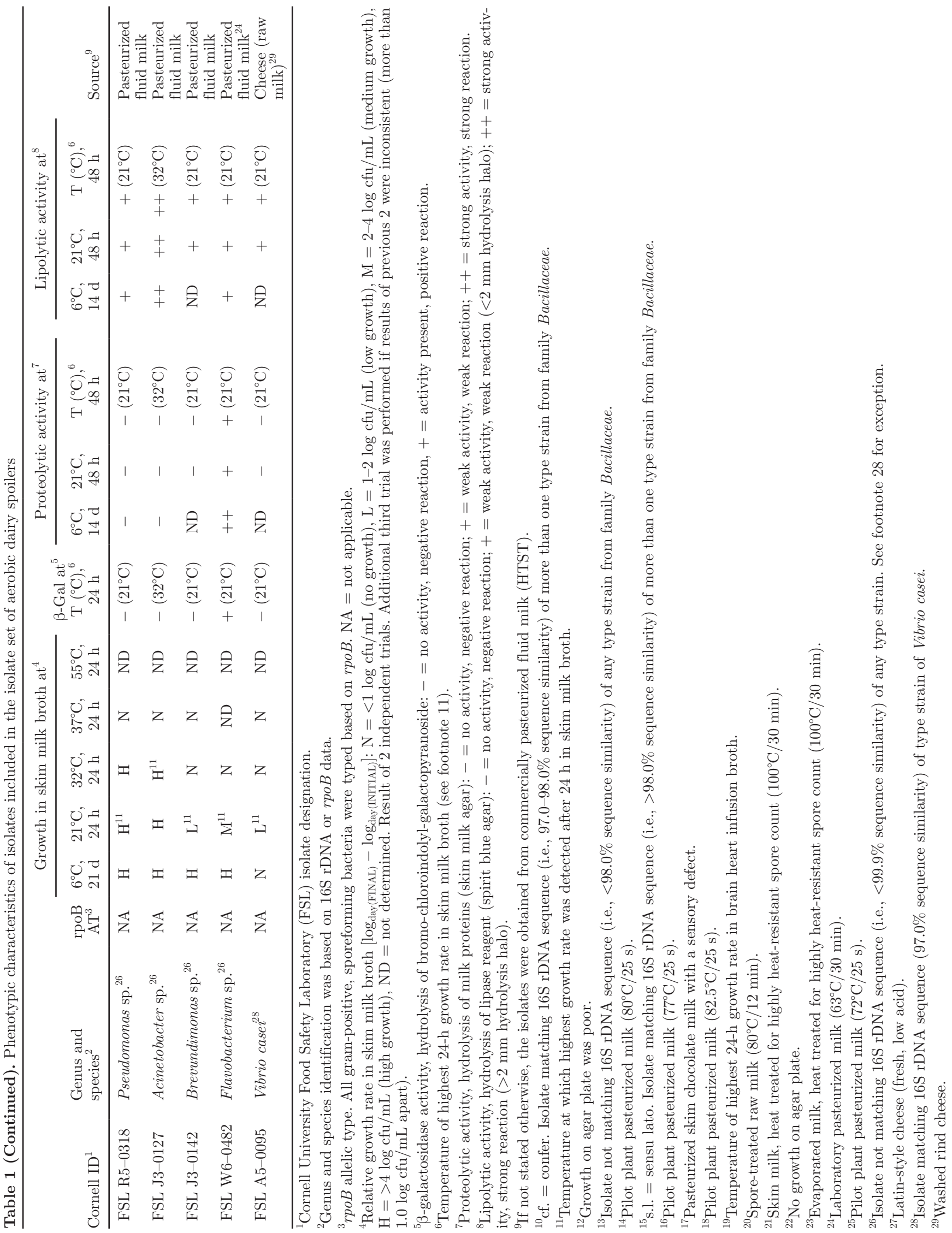


by the Life Sciences Core Laboratory Center (Cornell University).

\section{Determination of Isolate Growth Characteristics in Skim Milk Broth at Different Temperatures}

To assess growth in skim milk broth (SMB; BD, Franklin Lakes, NJ) at different temperatures, all isolates were first plated on BHI agar. Following overnight incubation at the appropriate temperature $(21,32,37$, or $55^{\circ} \mathrm{C}$ ), a single colony was inoculated into $5 \mathrm{~mL}$ of BHI broth and incubated aerobically at the same temperature used to initially grow an isolate on BHI agar. After 18 to $24 \mathrm{~h}$ of incubation (plating showed that bacterial numbers ranged between $1.1 \times 10^{5}$ and 1.7 $\left.\times 10^{9} \mathrm{cfu} / \mathrm{mL}\right), 1 \mathrm{~mL}$ of culture was pelleted $(13,000$ $\mathrm{rpm} / 1 \mathrm{~min}$ ), and the cell pellet was resuspended in 1 $\mathrm{mL}$ of phosphate buffer. The resuspended cell pellet was serially diluted appropriately (to obtain an approximate cell concentration of $10^{3} \mathrm{cfu} / \mathrm{mL}$ ) and $1 \mathrm{~mL}$ of it was used to inoculate $9 \mathrm{~mL}$ of sterile SMB. The initial concentration at inoculation was between $10^{2}$ and $10^{3} \mathrm{cfu} / \mathrm{mL}$. The inoculated SMB was incubated at $21,32,37$, or $55^{\circ} \mathrm{C}$ for $24 \mathrm{~h}$, and bacterial numbers were enumerated by spiral-plating appropriate dilutions on BHI agar (Difco, BD) using Autoplate 4000 (Spiral Biotech, Norwood, MA). Bacterial colonies were counted after 24 to $48 \mathrm{~h}$ (depending on colony growth morphology) using a Q-count (Spiral Biotech). When assessing the cold growth, the inoculated SMB was held for $21 \mathrm{~d}$ at $6^{\circ} \mathrm{C}\left( \pm 0.5^{\circ} \mathrm{C}\right)$, and the bacterial numbers were evaluated after 14 and $21 \mathrm{~d}$. All growth tests were performed in 2 repetitions; if the bacterial numbers of 2 repetitions were not within $1 \mathrm{log}$, a third growth test was performed. When assessing cold growth at $6^{\circ} \mathrm{C}$, a third growth test was performed if bacterial numbers of the 2 repetitions were not within $1 \log$ at either 14 or 21 $\mathrm{d}$ of incubation. The growth data were used to calculate the growth rate by subtracting the initial-day concentration from the final-day concentration $\left[\log _{\text {day }}\right.$ (FINAL) $-\log _{\text {day }(\text { INITIAL) })}$.

\section{Determination of Enzymatic Activity}

To assess enzymatic activities (i.e., lipolytic, proteolytic, and $\beta$-galactosidase activity), isolates were first plated on BHI agar and incubated overnight at 21, 32, 37 , or $55^{\circ} \mathrm{C}$. A single colony from an overnight plate was subsequently streaked in duplicate on different agar plate media as detailed below to assess specific enzymatic activity. Each type of enzymatic activity was determined at the temperature at which individual isolates demonstrated the most rapid growth in SMB.
Proteolytic and lipolytic activity were additionally determined at 6 and $21^{\circ} \mathrm{C}$.

$\boldsymbol{\beta}$-Galactosidase Activity. A colony was streaked onto 2 BHI agar plates, one with and one without an overlay of $100 \mu \mathrm{L}$ of a $40-\mu \mathrm{g} / \mathrm{mL}$ solution of bromochloroindolyl-galactopyranoside (Gold Biotechnology, St. Louis, MO), followed by incubation at appropriate temperature $\left(21,32,37\right.$, and $\left.55^{\circ} \mathrm{C}\right)$ for $24 \mathrm{~h}$. Blue colonies on the plates containing bromo-chloroindolylgalactopyranoside were indicative of $\beta$-galactosidase activity.

Proteolytic Activity. A colony was streaked on skim milk agar (SMA; Difco). Plates were incubated at appropriate temperature $\left(21,32,37\right.$, and $\left.55^{\circ} \mathrm{C}\right)$ and analyzed after $48 \mathrm{~h}$ of incubation. When proteolytic activity was assessed at $6^{\circ} \mathrm{C}$, the plates were analyzed after $14 \mathrm{~d}$ of incubation. Each plate was scored on a 3 -point scale for proteolytic activity: $(-)$ was given to plates with no visible zone of clearing around the growth, (+) was given to plates with weak zone of clearing (with no defined edge) or to plates with zone of clearing (with defined edge) along only a part of the growth, and $(++)$ was given to plates with zone of clearing (with defined edge) around the entire length of the growth.

Lipolytic Activity. A colony was streaked on Spirit Blue agar (Difco) containing an emulsion of pre-prepared lipase reagent containing a mixture of Tributyrin and Polysorbate 80 (Difco). Plates were incubated at appropriate temperature $\left(21,32,37\right.$, and $\left.55^{\circ} \mathrm{C}\right)$ and analyzed after $48 \mathrm{~h}$ of incubation. When lipolytic activity was assessed at $6^{\circ} \mathrm{C}$, the plates were analyzed after $14 \mathrm{~d}$ of incubation. Each plate was scored on a 3-point scale for lipolytic activity: (-) was given to plates with no visible zone of clearing, $(+)$ was given to plates with weak (less than $2 \mathrm{~mm}$ ) zone of clearing, and $(++)$ was given to plates with strong (more than $2 \mathrm{~mm}$ ) zone of clearing around the bacterial growth.

\section{Internet-Based Access}

Data on all isolates presented in the isolate set of dairy spoilers, including source information, date of isolation, and partial 16S rDNA and rpoB sequences, can be found in the publicly available FoodMicrobeTracker database (http://www.foodmicrobetracker.com). FoodMicrobeTracker can be searched for individual isolates by use of the appropriate FSL ID (e.g., FSL A5-0030; see Table 1) to access information (Vangay et al., 2013).

\section{Isolate Availability}

The isolate set of dairy spoilers is maintained by the FSL. Request for isolates or more information should 
be addressed to the corresponding author of this article (M. Wiedmann).

\section{RESULTS}

\section{Major Groups and Associated Isolate Diversity}

Isolates included in this standard bacterial set of aerobic dairy spoilers are listed in Table 1 and are separated into 2 main groups, gram-positive and gramnegative bacteria; the gram-positive bacteria can be further separated based on their capability to form endospores. Different sporeforming, gram-positive bacteria represent a large part of this bacterial set, as these types of organisms represent a major challenge in both fluid milk spoilage and dairy-powder quality. Because the taxonomy of sporeforming, aerobic bacteria of the family Bacillaceae is in considerable flux with frequent reclassification and description of new species and genera, it is sometimes difficult to assign a species name to an isolate; selection of isolates for inclusion in the isolate set described here thus used rpoB AT, which allow for reliable classification into different genotypes. In a few cases, a given rpoB AT is represented in the set by 2 or 3 different isolates, for example if isolates with a given rpoB AT represented distinct phenotypic characteristics. In our isolate set, the genus Bacillus is represented by 9 isolates classified into 7 different rpo $B$ AT, whereas the genus Paenibacillus is represented by 15 isolates classified into 13 different rpoB AT. All 9 Bacillus isolates and 14 Paenibacillus isolates were obtained from samples of fluid milk by standard platecounting techniques. One Paenibacillus isolate (FSL H8-0551) and one Ureibacillus isolate (FSL W8-0352) were isolated from spore-treated raw milk $\left(80^{\circ} \mathrm{C} / 12\right.$ min). The remaining 3 sporeforming isolates (FSL W8-0149, W8-0150, W8-0331), obtained from various points of dairy-powder production, were isolated after heat treatment to select for highly heat-resistant spores $\left(100^{\circ} \mathrm{C} / 30 \mathrm{~min}\right)$. The nonsporeforming bacteria represented in this isolate set are lactic acid bacteria and other cocci that were obtained from either commercially pasteurized or pilot plant pasteurized milk or milk pasteurized using the "lab pasteurization" approach $\left(63^{\circ} \mathrm{C} / 30 \mathrm{~min}\right.$; Frank and Yousef, 2004).

Among the 16 gram-negative isolates included in the isolate set reported here, 7 represent coliforms and 4 represent Pseudomonas species commonly linked to PPC. Among the Pseudomonas isolates, isolate FSL W5-0203 is unique because it was the cause of blue color defect in cheese due to PPC (Martin et al., 2011a). Additionally, one isolate of each Acinetobacter, Brevundimonas, and Flavobacterium are included in the set to represent less common genera involved in PPC. Two coliform isolates, classified as Rahnella inusitata (FSL A6-0213) and Klebsiella sp. (FSL W5-0628), represent bacteria linked to the ropy milk defect; these isolates were obtained from ropy samples of pasteurized and raw milk, respectively. The isolate set also includes an isolate of Vibrio casei. This recently identified species was shown to be commonly identified in raw-milk cheese samples (Bleicher et al., 2010; Wolfe et al., 2014).

\section{Growth Characteristics}

An important factor in the ability of an isolate to cause spoilage of food products is its ability to grow and proliferate under the conditions found in the food product (e.g., $\mathrm{pH}$, water activity, and so on). We have tested all 51 isolates included in the isolates set described here for growth in SMB (see Table 1). Only one Bacillus isolate, B. weihenstephanensis FSL H7-0687, was able to grow at $6^{\circ} \mathrm{C}$. Whereas 8 Paenibacillus isolates and one Viridibacillus isolate (FSL R5-0213) exhibited high growth rates $(>4 \log \mathrm{cfu} / \mathrm{mL})$ at $6^{\circ} \mathrm{C}, 3$ Paenibacillus isolates (FSL R7-0269, A5-0031, R5-0192) were unable to grow at $6^{\circ} \mathrm{C}$. The 4 thermotolerant isolates (FSL W8-0149, W8-0150, W8-0331, W8-0352) were not tested for cold growth. Of 6 nonsporeforming, gram-positive bacteria, only Leuconostoc (FSL R5-0726) and Lactococcus (FSL W6-0449) isolates grew at $6^{\circ} \mathrm{C}$. Within the gramnegative group, 3 isolates (FSL W5-0628, W5-0777, A5-0095) were not able to grow in $\mathrm{SMB}$ at $6^{\circ} \mathrm{C}$; the 13 other gram-negative isolates were able to grow by more than $4 \log$ units at this temperature. These isolates are represented by the genus Pseudomonas (FSL W5-0203, W7-0098, R5-0202, R5-0318), coliform bacteria (FSL W4-0268, W4-0276, W4-0242, P4-0811, A6-0213, W4-0273), Acinetobacter sp. (FSL J3-0127), Brevundimonas sp. (FSL J3-0142), and Flavobacterium sp. (FSL W6-0482). The phenotype observed at $6^{\circ} \mathrm{C}$ identified the Rahnella isolate FSL A6-0213 as a strong producer of mucoid substances, consistent with its ability to cause a ropy defect in milk.

Two thermotolerant isolates, Aeribacillus sp. FSL W8-0331 and Ureibacillus sp. FSL W8-0352, as well the Paenibacillus sp. isolate FSL A5-0031, were unable to grow in SMB at any tested temperature. Whereas most of the Paenibacillus isolates $(\mathrm{n}=12)$ were not able to grow at temperatures above $32^{\circ} \mathrm{C}, 3$ Paenibacillus isolates were able to grow at $37^{\circ} \mathrm{C}$, including the isolate Paenibacillus peoriae FSL A5-0030, which showed its highest growth rate at this temperature. The thermotolerant isolate Anoxybacillus sp. FSL W8-0150 had similar growth rates at both 37 and $55^{\circ} \mathrm{C}$, whereas the Geobacillus isolate FSL W8-0149 grew only at $55^{\circ} \mathrm{C}$. Most of the isolates $(\mathrm{n}=6)$ within the Bacillus group were able to grow at $37^{\circ} \mathrm{C}$, except for $3 \mathrm{~B}$. weihenstepha- 
nensis isolates. All 6 nonsporeforming, gram-positive isolates were able to grow at $37^{\circ} \mathrm{C}$, whereas none of the Pseudomonas isolates grew at this temperature. The psychrotolerant isolates Rahnella inusitata FSL A60213 and Serratia sp. FSL P4-0811 were also unable to grow at $37^{\circ} \mathrm{C}$, whereas all other coliform isolates grew well at this temperature (with growth rates above 4 $\log \mathrm{cfu} / \mathrm{mL}$ ). Rahnella inusitata FSL A6-0213 exhibited poor production of mucoid substances at temperatures above $6^{\circ} \mathrm{C}$, whereas the Klebsiella isolate FSL W5-0628 produced these substances at 21,32 , and $37^{\circ} \mathrm{C}$. Most of the isolates $(\mathrm{n}=42)$ included in the isolate set were able to grow at temperatures 21 and $32^{\circ} \mathrm{C}$. For the Vibrio casei isolate FSL A5-0095, $21^{\circ} \mathrm{C}$ was the only tested temperature that allowed some growth within $24 \mathrm{~h}$.

\section{$\beta$-Galactosidase, Proteolytic, and Lipolytic Activity}

All 9 Bacillus isolates as well as Viridibacillus arenosi FSL R5-0213, Aeribacillus sp. FSL W8-0331 and Ureibacillus sp. W8-0352 were negative for $\beta$-galactosidase activity (Table 1 ). The other 2 thermotolerant isolates, Geobacillus sp. FSL W8-0149 and Anoxybacillus sp. FSL W8-0150, as well as all 15 Paenibacillus isolates were positive for $\beta$-galactosidase. Lactic acid bacteria (FSL R5-0726, W5-0563, W6-0449) were the only nonsporeforming, gram-positive bacteria that were positive for $\beta$-galactosidase. Among the gram-negative bacteria, all 8 coliform isolates as well as one noncoliform ( Flavobacterium sp. FSL W6-0482) isolate were positive for $\beta$-galactosidase activity. All 4 Pseudomonas isolates as well as 3 other noncoliform isolates (FSL J3-0127, J3-0142, A5-0095) were negative for $\beta$-galactosidase activity.

Seven Bacillus isolates were positive for proteolytic activity on SMA. The 2 Bacillus isolates negative for proteolytic activity were $B$. licheniformis FSL H7-0968 and B. muralis FSL J3-0137. The thermotolerant isolates Aeribacillus pallidus FSL W8-0331 and Ureibacillus sp. FSL W8-0352 were unable to grow in SMB or on SMA. The thermotolerant isolates Geobacillus sp. FSL W8-0149 and Anoxybacillus sp. FSL W8-0150, which did grow on SMA, exhibited no proteolytic activity. All 3 P. peoriae-group isolates as well as Paenibacillus amylolyticus s.l. FSL R5-0192 and Paenibacillus isolate FSL R7-0277 tested positive for proteolytic activity. The other 10 Paenibacillus isolates, including all $4 P$. odorifer isolates, were negative for proteolytic activity. Among the nonsporeforming, gram-positive bacteria, only Micrococcus sp. FSL W5-0353 showed proteolytic activity. Two Pseudomonas isolates (FSL W5-0203, R5-0202) had a strong proteolytic activity at all tested temperatures. Isolate Pseudomonas fragi (FSL W70098) was positive for proteolytic activity only when incubated at $6^{\circ} \mathrm{C}$ for $14 \mathrm{~d}$, whereas one Pseudomonas isolate (FSL R5-0318) tested negative for proteolytic activity at all tested temperatures. Flavobacterium sp. FSL W6-0482 exhibited proteolytic activity at 6 and $21^{\circ} \mathrm{C}$. Klebsiella sp. isolate FSL W5-0628 and Serratia sp. isolate FSL P4-0811 were the only 2 coliforms with detected proteolytic activity.

All 9 Bacillus isolates, all 3 P. amylolyticus s.l. isolates, as well as the Paenibacillus xylanilyticus and Paenibacillus pabuli isolate FSL H8-0287 and V. arenosi FSL R5-0213 were positive for lipolytic activity at all tested temperatures that supported growth. Five Paenibacillus isolates (FSL R5-0808, R7-0277, A5-0031, J3-0120, H8-0551) were positive for lipolytic activity only at $6^{\circ} \mathrm{C}$. All $4 \mathrm{P}$. odorifer isolates, as well as 2 other Paenibacillus isolates (FSL R7-0269, A5-0030), tested negative for lipolytic activity. Aeribacillus pallidus (FSL W8-0331) is the only thermotolerant isolate negative for lipolytic activity. Within the group of nonsporeforming, gram-positive bacteria, Micrococcus sp. (FSL W5-0353) is the only isolate positive for lipolytic activity. Two nonpsychrotolerant coliform isolates, Escherichia fergusonii (FSL W5-0777) and Klebsiella sp. (FSL W5-0628), were positive for lipolytic activity, whereas Serratia sp. FSL P4-0811 was the only psychrotolerant coliform isolate positive for lipolytic activity. All 8 noncoliform, gram-negative isolates, including all 4 Pseudomonas isolates, were positive for lipolytic activity at all tested temperatures.

\section{DISCUSSION}

Publicly available isolate sets are a well-established way of providing relevant microbial isolates for research and development. Although many microbial sets are established and available for foodborne pathogens [e.g., Salmonella (Boyd et al., 1993), E. coli (Ochman and Selander, 1984)], no current isolate sets exist that focus on industry-specific organisms responsible for food spoilage. This manuscript reports the establishment of one such isolate set, which consists of various isolates responsible for spoilage of milk and dairy products.

\section{Taxonomic, Phenotypic, and Genotypic Diversity of Isolate Set in Relation to Known Dairy-Spoilage Organisms}

This Standard Bacterial Set for Research on Current Dairy Spoilage consists of 51 individual isolates, including 35 gram-positive and 16 gram-negative isolates. Because fluid milk represents the most perishable dairy product, most of the isolates represented in this set originate from pasteurized milk, with additional isolates from pasteurized chocolate milk and raw milk. 
The bacterial set also includes 4 relevant isolates originating from dairy-powder production and 2 isolates from cheese.

Gram-positive isolates include several nonsporeforming (e.g., Staphylococcus and lactic acid bacteria) as well as a large number of sporeforming bacteria. Sporeforming bacteria are represented predominately by genera Bacillus and Paenibacillus, which have previously been shown to be important dairy-spoilage organisms (Huck et al., 2007a; Ledenbach and Marshall, 2009; Ranieri and Boor, 2009; Ranieri et al., 2012). From our previous study (Ivy et al., 2012) we included isolates with rpoB AT representing the 3 most prominent dairy-associated Bacillus clades, one isolate representing a less common clade (B. muralis), and also a Viridibacillus isolate as a representative of the fourth prominent clade. The strains were also selected to represent rpoB AT of the 5 most prominent Paenibacillus clades (V, VII, VIII, $\mathrm{XI}, \mathrm{X}$ ) associated with dairy. For some clades or rpoB AT, we selected multiple isolates to represent phenotypic diversity. For example, our isolate set includes 3 $B$. weihenstephanensis isolates, including 2 with $r p o B$ AT3; these isolates exhibit different proteolytic and cold growth capabilities. Another example are the $3 P$. amylolyticus s.l. rроB AT23 isolates, which are exhibiting none, medium, and high level of growth at $6^{\circ} \mathrm{C}$; the isolate unable to grow at cold temperature is also the only of 3 isolates that exhibits any proteolytic activity on SMA.

Our isolate set also includes gram-positive sporeforming bacteria that originate from production of dairy powder. These isolates were obtained from samples collected at various points of dairy-powder production (Watterson et al., 2014) and represent both standard thermophilic bacteria (Ureibacillus sp.) that produce spores able to survive heat treatment of $80^{\circ} \mathrm{C} / 12 \mathrm{~min}$, as well as so-called highly heat-resistant thermophilic bacteria (Geobacillus sp., Anoxybacillus sp., and Aeribacillus pallidus) that produce spores able to survive heat treatment at $100^{\circ} \mathrm{C} / 30 \mathrm{~min}$. All 4 genera were previously reported as contaminants of dairy powder and dairy-powder production facilities (Rückert et al., 2004; Burgess et al., 2010; Lücking et al., 2013; Watterson et al., 2014). Isolates representing the genus Anoxybacillus were identified as the most prevalent bacterial contaminants in dairy powders and a common problem in dairy-powder production regardless of geographic location (Rückert et al., 2004). Different species of the genus Geobacillus are also frequently identified as contaminants of dairy powders and inhabitants of dairypowder production facilities (Ronimus et al., 2003). Aeribacillus pallidus (formerly known as Geobacillus pallidus; Miñana-Galbis et al., 2010) has also been reported as a dominant species, in dairy powders, that produces highly thermoresistant spores (Lücking et al., 2013). These bacterial contaminants are generally regarded as hygiene indicators, and only a small part of them can cause actual product defect. The biggest factor in being able to cause product defect is the ability to produce different hydrolytic enzymes (Burgess et al., 2010). Our isolate set includes isolates with and without $\beta$-galactosidase activity, as well as isolates with various degrees of lipolytic activity.

Although nonsporeforming, gram-positive bacteria are less common as dairy-spoilage organisms, they are well documented contaminants of raw milk and the dairy-processing environment (Cleto et al., 2012). This group of bacteria can cause PPC and spoilage of fluid milk and other dairy products (Ledenbach and Marshall, 2009; Martin et al., 2011b). Our isolate set includes an isolate Leuconostoc lactis from a commercially pasteurized milk (Ranieri and Boor, 2009), as well as several isolates obtained from laboratory pasteurization of raw milk. Heat treatments of milk samples from which these isolates were obtained include $63^{\circ} \mathrm{C} / 30 \mathrm{~min}$ (Lactococcus lactis, Enterococcus sp.), $72^{\circ} \mathrm{C} / 25 \mathrm{~s}$ (Micrococcus sp., Streptococcus thermophilus), and $77^{\circ} \mathrm{C} / 25$ s (Staphylococcus pasteuri; Caplan et al., 2013).

Gram-negative isolates included in the isolate set represent key spoilage organisms, previously identified as important in dairy products (Dogan and Boor, 2003; Hantsis-Zacharov and Halpern, 2007; Ledenbach and Marshall, 2009; Martin et al., 2012a), including Pseudomonas, Acinetobacter, Brevundimonas, Flavobacterium, and various coliform bacteria. Four Pseudomonas isolates were included in our set to represent genotypic and phenotypic as well as isolation source diversity. One Pseudomonas fluorescens isolate was obtained from a cheese sample with a blue color defect (Martin et al., 2011a), and the other 3 are fluid milk isolates (Ranieri and Boor, 2009), which were also previously used by our group to evaluate various selective media for detection of Pseudomonas species (Van Tassell et al., 2012).

In another study from our group, on milk contamination with psychrotolerant coliform bacteria, 5 genera (Enterobacter, Hafnia, Citrobacter, Serratia, and Raoultella) were identified as the most prevalent (S. N. Masiello, Cornell University, Ithaca, NY, personal communication). Representatives of all 5 prevalent psychrotolerant coliform genera are included in this isolate set. The genus Enterobacter was the most prevalent genus in fluid milk, and the specific Enterobacter isolate (FSL W4-0242) included in the isolate set represents the most prevalent $16 \mathrm{~S}$ rDNA sequence type among all psychrotolerant coliforms isolated from different fluid-milk samples. We also included a representative of a less prevalent psychrotolerant genus, Rahnella. This isolate was classified as Rahnella inusitata (formerly 
known as Genomspecies 3 of genus Rahnella; Brady et al., 2014) and was obtained from pasteurized milk exhibiting a ropy defect. Additionally, we included a Klebsiella sp. isolate, which was obtained from a rawmilk sample that showed a ropy defect. The genus Klebsiella has previously been identified as the causative organism of ropy milk (Cheung and Westhoff, 1983). Although the Klebsiella sp. ropy milk isolate is able to produce mucoid substances and cause ropiness, it is not capable of growing at refrigeration temperatures; the Rahnella inusitata isolate is capable of cold growth and will cause a substantial ropy defect within $21 \mathrm{~d}$ of incubation at $6^{\circ} \mathrm{C}$. Although rare (Mader, 1940; Cheung and Westhoff, 1983), the ropy defect in milk is severe and will require additional research to characterize the causative organisms and develop strategies to eliminate this type of contamination. In addition to these coliform isolates discussed above, we also included in our isolate set an isolate of Escherichia fergusonii. Based on DNA-DNA hybridization (60\% similarity), E. fergusonii is the closest relative of E. coli (Lawrence et al., 1991) and most likely often times interpreted as E. coli when using classical counting and identification methods. In an on-going study by our group (A. Trmčić, unpublished data), E. fergusonii was identified as the most prevalent coliform in raw and pasteurized cheese; hence, inclusion of this species in this isolate set was deemed appropriate.

We characterized the isolates included in this isolate set by determining growth in SMB, proteolytic and lipolytic activity at different temperatures, as well as presence of $\beta$-galactosidase. This basic characterization provides important initial information that will allow others to select isolates for further characterization. One of the future steps in characterization should be to fully identify and classify isolates included in this isolate set by full genome sequencing. Full genome sequencing and other molecular biology tools can also help identify the genomic features responsible for spoilage potential of these isolates. Nine gram-positive sporeforming isolates featured in this isolate set were already included in a recent comparative full-genome study performed by our group (Moreno Switt et al., 2014). The results of this study identified several different genomic features involved in the ability of strains to grow and spoil refrigerated fluid milk but also opened some questions that need to be addressed in the future. Upcoming work will include a comparative full-genome study on bacteria that cause ropy milk defect (A. Trmčić, unpublished data), using 2 of the isolates included in the isolates set described here.

Although this isolate set does represent the key aerobic spoilage bacteria associated with the dairy environment, other aerobic as well as anaerobic spoilage bacteria (e.g., C. tyrobutyricum) still need to be added to comprehensively capture the entire range of dairyassociated spoilage microorganisms. Furthermore, yeasts and molds are becoming increasingly important as spoilage organisms, and they too need to be eventually included in the dairy-spoilage isolate set.

\section{Potential Applications of the Isolate Set}

The isolates included in this standard set of dairyspoilage bacteria can be used in studies dealing with different aspects of spoilage characterization, detection, and prevention. One use of this set should be to obtain basic knowledge on the adaptation and survival of spoilage organisms under different dairy-relevant conditions (Huck et al., 2007a; Masiello et al., 2014). Use of these isolates to further study mechanisms involved in microbial spoilage of dairy products (e.g., identification of specific enzymes responsible for defects such as ropy milk) would not only provide relevant basic scientific information, but could also help to develop novel strategies to prevent and minimize dairy spoilage. Genomic studies on individual spoilage organisms already proved to be useful in this regard (Moreno Switt et al., 2014), but these studies must also be supported by phenotypic or even epigenetic studies.

The standard set of dairy-spoilage bacteria reported here will also be valuable for the evaluation of established and the development of new detection methods as well as control and prevention strategies. Many of the methods used for evaluation of dairy-product quality have been in use for decades, despite the vast improvement in dairy and milk quality (Boor, 2001; Martin et al., 2012a), identification and possibly emergence of new spoilage organisms (Ranieri and Boor, 2009; Ivy et al., 2012), and technological and processing advances (Martín et al., 2010; Ranieri et al., 2012; Masiello et al., 2014). Thus, the need exists to validate and develop detection and control methods for spoilage organisms, which requires a relevant isolate set that represents the current organisms of interest and relevance to the dairy industry. For example, the isolates described here could be used as target organisms in controlled challenge tests and are likely to represent the range of behavior of spoilage organisms in a real production process.

\section{CONCLUSIONS}

Although this isolate set represents a wide range of the bacterial dairy-spoilage organisms known today, further development and expansion of this isolate set will be necessary to capture the diversity and dynamic nature of microbial spoilage. Importantly, this isolate set does not yet include anaerobic spoilage organisms 
or spoilage yeast and molds. This isolate set, together with data curation in FoodMicrobeTracker (http:// www.foodmicrobetracker.com), already provides a unique resource though that will help advance knowledge of dairy-spoilage organisms as well as aid industry in developing new control strategies. Isolates included in this set have already been used by our group in several different research studies (Ranieri et al., 2009; Martin et al., 2011a, 2012a,b; Ivy et al., 2012; Van Tassell et al., 2012; Moreno Switt et al., 2014) and have also been distributed to other research groups and industry partners.

\section{ACKNOWLEDGMENTS}

This publication was made possible by an unrestricted gift from Chobani Inc. (Norwich, NY), supporting dairy spoilage research, as well as research funding provided by Dairy Management Inc. (Rosemont, IL) and administered by Dairy Research Institute (Rosemont, IL). We also thank Alexis Andrus, Clint Hervert, Yumin Xu, and Kristen Kurtz, from Cornell University (Ithaca, NY), for their contributions in putting together this isolate set.

\section{REFERENCES}

Bleicher, A., K. Neuhaus, and S. Scherer. 2010. Vibrio casei sp. nov., isolated from the surfaces of two French red smear soft cheeses. Int. J. Syst. Evol. Microbiol. 60:1745-1749. http://dx.doi. org/10.1099/ijs.0.016493-0.

Boor, K. J. 2001. Fluid dairy product quality and safety: Looking to the future. J. Dairy Sci. 84:1-11.

Boyd, E. F., F. S. Wang, P. Beltran, S. A. Plock, K. Nelson, and R. K. Selander. 1993. Salmonella reference collection B (SARB): Strains of 37 serovars of subspecies I. J. Gen. Microbiol. 139:1125-1132.

Brady, C., G. Hunter, S. Kirk, D. Arnold, and S. Denman. 2014. Rahnella victoriana sp. nov., Rahnella bruchi sp. nov., Rahnella woolbedingensis sp. nov., classification of Rahnella genomospecies 2 and 3 as Rahnella variigena sp. nov. and Rahnella inusitata sp. nov., respectively and emended description of the genus Rahnella. Syst. Appl. Microbiol. 37:545-552. http://dx.doi.org/10.1016/j. syapm.2014.09.001.

Burgess, S. A., D. Lindsay, and S. H. Flint. 2010. Thermophilic bacilli and their importance in dairy processing. Int. J. Food Microbiol. 144:215-225. http://dx.doi.org/10.1016/j.ijfoodmicro.2010.09.027.

Caplan, Z., C. Melilli, and D. M. Barbano. 2013. Gravity separation of fat, somatic cells, and bacteria in raw and pasteurized milks. J. Dairy Sci. 96:2011-2019. http://dx.doi.org/10.3168/jds.20126006.

Cheung, B. A., and D. C. Westhoff. 1983. Isolation and identification of ropy bacteria in raw-milk. J. Dairy Sci. 66:1825-1834.

Cleto, S., S. Matos, L. Kluskens, and M. J. Vieira. 2012. Characterization of contaminants from a sanitized milk processing plant. PLoS ONE 7:e40189 http://dx.doi.org/10.1371/journal.pone.0040189.

Cogan, T. M., and T. P. Beresford. 2002. Microbiology of hard cheese. Pages 515-560 in Dairy Microbiology Handbook. R. K. Robinson, ed. John Wiley Sons, New York, NY.

Dogan, B., and K. J. Boor. 2003. Genetic diversity and spoilage potentials among Pseudomonas spp. isolated from fluid milk products and dairy processing plants. Appl. Environ. Microbiol. 69:130 138.
Dugan, K. A., H. S. Lawrence, D. R. Hares, C. L. Fisher, and B. Budowle. 2002. An improved method for post-PCR purification for mtDNA sequence analysis. J. Forensic Sci. 47:811-818.

Frank, J. F., and A. E. Yousef. 2004. Tests for groups of microorganisms. Pages 227-248 in Standard Methods for the Examination of Dairy Products. H. M. Wehr and J. F. Frank, ed. Am. Pub. Health Assoc., Washington, DC.

Fugett, E., E. Fortes, C. Nnoka, and M. Wiedmann. 2006. International Life Sciences Institute North America Listeria monocytogenes strain collection: Development of standard Listeria monocytogenes strain sets for research and validation studies. J. Food Prot. 69:2929-2938.

Golan, E., and J. C. Buzby. 2015. Innovating to meet the challenge of FOOD WASTE. Food Technol. 69:21-25.

Hantsis-Zacharov, E., and M. Halpern. 2007. Culturable psychrotrophic bacterial communities in raw milk and their proteolytic and lipolytic traits. Appl. Environ. Microbiol. 73:7162-7168. http:// dx.doi.org/10.1128/AEM.00866-07.

Huck, J. R., B. H. Hammond, S. C. Murphy, N. H. Woodcock, and K. J. Boor. 2007a. Tracking spore-forming bacterial contaminants in fluid milk-processing systems. J. Dairy Sci. 90:4872-4883. http:// dx.doi.org/10.3168/jds.2007-0196.

Huck, J. R., M. Sonnen, and K. J. Boor. 2008. Tracking heat-resistant, cold-thriving fluid milk spoilage bacteria from farm to packaged product. J. Dairy Sci. 91:1218-1228. http://dx.doi.org/10.3168/ jds.2007-0697.

Huck, J. R., N. H. Woodcock, R. D. Ralyea, and K. J. Boor. 2007b. Molecular subtyping and characterization of psychrotolerant endospore-forming bacteria in two New York State fluid milk processing systems. J. Food Prot. 70:2354-2364.

Ivy, R. A., J. M. Farber, F. Pagotto, and M. Wiedmann. 2013. International Life Science Institute North America Cronobacter (Formerly Enterobacter sakazakii) isolate set. J. Food Prot. 76:40-51. http://dx.doi.org/10.4315/0362-028X.JFP-11-546.

Ivy, R. A., M. L. Ranieri, N. H. Martin, H. C. den Bakker, B. M. Xavier, M. Wiedmann, and K. J. Boor. 2012. Identification and characterization of psychrotolerant sporeformers associated with fluid milk production and processing. Appl. Environ. Microbiol. 78:1853-1864. http://dx.doi.org/10.1128/AEM.06536-11.

Janezic, S., V. Zidaric, B. Pardon, A. Indra, B. Kokotovic, J. L. Blanco, C. Seyboldt, C. R. Diaz, I. R. Poxton, V. Perreten, I. Drigo, A. Jiraskova, M. Ocepek, J. S. Weese, J. G. Songer, M. H. Wilcox, and M. Rupnik. 2014. International Clostridium difficile animal strain collection and large diversity of animal associated strains. BMC Microbiol. 14:173 http://dx.doi.org/10.1186/1471-2180-14173.

Lawrence, J. G., H. Ochman, and D. L. Hartl. 1991. Molecular and evolutionary relationships among enteric bacteria. J. Gen. Microbiol. 137:1911-1921.

Ledenbach, L. H. and R. T. Marshall. 2009. Microbiological spoilage of dairy products. Compendium of the microbiological spoilage of foods and beverages. Pages 41-67 in Food Microbiology and Food Safety. Springer Sci.+Bus. Media, New York, NY. 10.1007/978-14419-0826-1_2.

Lemieux, L., and R. E. Simard. 1992. Bitter favour in dairy products. II. A review of bitter peptides from caseins: Their formation, isolation and identification, structure masking and inhibition. Lait $72: 335-385$.

Lücking, G., M. Stoeckel, Z. Atamer, J. Hinrichs, and M. EhlingSchulz. 2013. Characterization of aerobic spore-forming bacteria associated with industrial dairy processing environments and product spoilage. Int. J. Food Microbiol. 166:270-279. http:// dx.doi.org/10.1016/j.ijfoodmicro.2013.07.004.

Mader, C. K. 1940. Ropy milk, Its cause and prevention. Can. J. Comp. Med. Vet. Sci. 4:203-205.

Martín, M. C., N. Martinez, B. del Rio, V. Ladero, M. Fernandez, and M. A. Alvarez. 2010. A novel real-time polymerase chain reaction-based method for the detection and quantification of lactose-fermenting Enterobacteriaceae in the dairy and other food industries. J. Dairy Sci. 93:860-867. http://dx.doi.org/10.3168/ jds.2009-2481. 
Martin, N. H., N. R. Carey, S. C. Murphy, M. Wiedmann, and K. J. Boor. 2012a. A decade of improvement: New York State fluid milk quality. J. Dairy Sci. 95:7384-7390. http://dx.doi.org/10.3168/ jds.2012-5767.

Martin, N. H., S. C. Murphy, R. D. Ralyea, M. Wiedmann, and K. J. Boor. 2011a. When cheese gets the blues: Pseudomonas fluorescens as the causative agent of cheese spoilage. J. Dairy Sci. 94:31763183. http://dx.doi.org/10.3168/jds.2011-4312.

Martin, N. H., M. L. Ranieri, S. C. Murphy, R. D. Ralyea, M. Wiedmann, and K. J. Boor. 2011b. Results from raw milk microbiological tests do not predict the shelf-life performance of commercially pasteurized fluid milk. J. Dairy Sci. 94:1211-1222. http://dx.doi. org/10.3168/jds.2010-3915.

Martin, N. H., M. L. Ranieri, M. Wiedmann, and K. J. Boor. 2012b. Reduction of pasteurization temperature leads to lower bacterial outgrowth in pasteurized fluid milk during refrigerated storage: A case study. J. Dairy Sci. 95:471-475. http://dx.doi.org/10.3168/ jds.2011-4820.

Masiello, S. N., N. H. Martin, R. D. Watters, D. M. Galton, Y. H. Schukken, M. Wiedmann, and K. J. Boor. 2014. Identification of dairy farm management practices associated with the presence of psychrotolerant sporeformers in bulk tank milk. J. Dairy Sci. 97:4083-4096. http://dx.doi.org/10.3168/jds.2014-7938.

Miñana-Galbis, D., D. L. Pinzon, J. G. Loren, A. Manresa, and R. M. Oliart-Ros. 2010. Reclassification of Geobacillus pallidus (Scholz et al. 1988) Banat et al. 2004 as Aeribacillus pallidus gen. nov., comb. nov. Int. J. Syst. Evol. Microbiol. 60:1600-1604. http://dx.doi. org/10.1099/ijs.0.003699-0.

Moreno Switt, A. I., A. D. Andrus, M. L. Ranieri, R. H. Orsi, R. Ivy, H. C. den Bakker, N. H. Martin, M. Wiedmann, and K. J. Boor. 2014. Genomic comparison of sporeforming bacilli isolated from milk. BMC Genomics 15:26 http://dx.doi.org/10.1186/14712164-15-26.

Ochman, H., and R. K. Selander. 1984. Standard reference strains of Escherichia coli from natural populations. J. Bacteriol. 157:690693.

Ranieri, M. L., and K. J. Boor. 2009. Short communication: Bacterial ecology of high-temperature, short-time pasteurized milk processed in the United States. J. Dairy Sci. 92:4833-4840. http:// dx.doi.org/10.3168/jds.2009-2181.

Ranieri, M. L., J. R. Huck, M. Sonnen, D. M. Barbano, and K. J. Boor. 2009. High temperature, short time pasteurization temperatures inversely affect bacterial numbers during refrigerated storage of pasteurized fluid milk. J. Dairy Sci. 92:4823-4832. http:// dx.doi.org/10.3168/jds.2009-2144.

Ranieri, M. L., R. A. Ivy, R. Mitchell, E. Call, S. N. Masiello, M. Wiedmann, and K. J. Boor. 2012. Real-time PCR detection of Paenibacillus spp. in raw milk to predict shelf life performance of pasteurized fluid milk products. Appl. Environ. Microbiol. 78:5855-5863. http://dx.doi.org/10.1128/AEM.01361-12.

Remenant, B., E. Jaffrès, X. Dousset, M.-F. Pilet, and M. Zagorec. 2015. Bacterial spoilers of food: Behavior, fitness and functional properties. Food Microbiol. 45:45-53. http://dx.doi. org/10.1016/j.fm.2014.03.009.

Ronimus, R. S., L. E. Parker, N. Turner, S. Poudel, A. Ruckert, and H. W. Morgan. 2003. A RAPD-based comparison of thermophilic bacilli from milk powders. Int. J. Food Microbiol. 85:45-61.

Rückert, A., R. S. Ronimus, and H. W. Morgan. 2004. A RAPDbased survey of thermophilic bacilli in milk powders from different countries. Int. J. Food Microbiol. 96:263-272. http://dx.doi. org/10.1016/j.ijfoodmicro.2004.03.020.

USDA. 2012. All Dairy Products: Per capita availability adjusted for loss. Accessed Apr. 10, 2015. http://search.ers.usda.gov/ search?affiliate $=$ ers\&query $=$ www.ers.usda.gov $/$ datafiles $/$ Food_ Availabily_Per_Capita_Data_System/LossAdjusted_Food_ Availability/Dairy.xls\%20per\%20capita\%20availability\%20 adjusted $\% 20$ for $\% 20$ loss.

Van Tassell, J. A., N. H. Martin, S. C. Murphy, M. Wiedmann, K. J. Boor, and R. A. Ivy. 2012. Evaluation of various selective media for the detection of Pseudomonas species in pasteurized milk. J. Dairy Sci. 95:1568-1574. http://dx.doi.org/10.3168/jds.20114958.

Vangay, P., E. B. Fugett, Q. Sun, and M. Wiedmann. 2013. Food microbe tracker: A web-based tool for storage and comparison of food-associated microbes. J. Food Prot. 76:283-294. http:// dx.doi.org/10.4315/0362-028X.JFP-12-276.

Watterson, M. J., D. J. Kent, K. J. Boor, M. Wiedmann, and N. H. Martin. 2014. Evaluation of dairy powder products implicates thermophilic sporeformers as the primary organisms of interest. J. Dairy Sci. 97:2487-2497. http://dx.doi.org/10.3168/jds.20137363.

Wolfe, B. E., J. E. Button, M. Santarelli, and R. J. Dutton. 2014 Cheese rind communities provide tractable systems for in situ and in vitro studies of microbial diversity. Cell 158:422-433. http:// dx.doi.org/10.1016/j.cell.2014.05.041. 